\title{
A note on chromosome abnormalities in early turkey embryos
}

\author{
K. Jaszczak ${ }^{1}$, R. Parada and M. Sacharczuk \\ Department of Molecular Cytogenetics, \\ Institute of Genetics and Animal Breeding, \\ Polish Academy of Sciences \\ Jastrzębiec, 05-552 Wólka Kosowska, Poland
}

(Received 10 April 2003; accepted 28 October 2003)

\begin{abstract}
Two commercial turkey lines: medium-heavy weight (MHW) and heavy-weight (HW) were used for a karyotype analysis and study of the frequency of chromosome abnormalities in early embryos $(24 \mathrm{~h})$. Among the total of 378 embryos, 40 (10.5\%) had an abnormal chromosome complement consisting of 14 haploids, 20 haploid-diploid chimeras, 2 triploids and 4 diploid-tetraploid mosaics. A significantly greater frequency of heteroploid embryos was recovered from the MHW (15.4\%) than from the HW line $(8.0 \%)$. The discussion points to the negative effect of chromosome abnormalities on hatchability.
\end{abstract}

KEY WORDS: embryos, chromosome abnormalities, turkey

\section{INTRODUCTION}

An analysis of the chromosome complements of early chicken embryos has revealed that in domestic fowl various types of chromosome abnormalities can occur, including haploidy, triploidy, aneuploidy (Bloom, 1972; Miller et al., 1976). The chromosome abnormalities are caused principally by meiotic nondisjunction, polar body suppression during oogenesis, polyspermy and errors during early cleavage (Fechheimer, 1981). The level of spontaneous chromosome aberrations in chicken varies depending on line, stock, breed and direction of selection (Reddy and Siegel, 1977; Snyder et al., 1979; Jaszczak et al., 1992). Chromosome abnormalities in avian embryos can be responsible for their high mortality and hatching

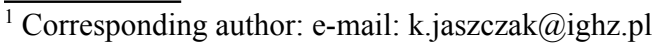


losses (Thorne et al., 1991; Jaszczak and Jaszczak, 1993). Elimination from the breeding stock of families or individuals producing a high proportion of chromosome abnormalities among the embryos may be of considerable practical importance.

A majority of karyotype studies performed on poultry were related to chicken and sporadically quail or geese (de la Sena et al., 1992; Jaszczak et al., 1999). Cytogenetic investigations of turkey embryos were not conducted, despite the fact that this species is very important for poultry meat production. The aim of the present studies was to estimate the frequency of chromosome abnormalities in early embryos of two turkey commercial lines.

\section{MATERIAL AND METHODS}

The cytogenetic study was carried out on embryos from two commercial lines of turkeys: Nicholas 300 (medium-heavy weight MHW) and Nicholas 700 (heavyweight HW). Samples were collected over a period of one season - from April to July. Eggs were collected and stored at $12^{\circ} \mathrm{C}$ for two weeks and then placed in an incubator at $38^{\circ} \mathrm{C}$. After $24 \mathrm{~h}$ incubation the eggs were opened and examined macroscopically. The blastodisks from fertile eggs were removed and each was turned into a cell suspension in $2 \mathrm{ml}$ of culture medium containing colchicine. Further processing included short culture $(2 \mathrm{~h})$, hypotonic, fixation and slide preparation, according to the method described by Zartman and Jaszczak (1980). Five to 10 methaphase spreads were analysed by scoring the presence of the 9 largest pairs of autosomes and sex chromosomes ZZ and ZW. When karyotype abnormalities were detected 20 to 30 metaphases were analysed (if available). The karyotype analysis was carried out under a light microscope with CCD camera connected to a computer supplied with o Multiscan analytic programme.

Differences between the two turkeys lines were estimated by the chi-square test.

\section{RESULTS AND DISCUSSION}

Results of the cytogenetic survey of early embryos ( $24 \mathrm{~h}$ ) from two lines of turkeys are given in Table 1 . Among 378 turkey embryos 40 (10.5\%) were composed of cells with abnormal chromosome complements.

Among 40 embryos with an abnormal karyotype 34 contained haploid cells, either alone or in conjunction with diploid cells. The remaining aberrations included 4 diploid/tetraploid mosaics and 2 triploids. A significantly greater frequency of chromosomal abnormalities was recovered from the MHW (15.4\%) than the HW line $(8.0 \%)$. The frequency of pure haploidy (1A) was specially high in line 
MHW, while the frequency of other heteroploidy types were relatively low in both lines. The sex chromosome complements of aberrant turkey embryos are showed in Table 2. In haploid embryos and in haploid cells from the haploid/diploid chimeras only the $\mathrm{Z}$ sex chromosome was observed. Chromosome $\mathrm{W}$ was not found. This suggests that, similarly as in chicken, haploid cell lines in embryos, either pure haploidy (1A) or haploid/diploid chimerism, are of androgenetic origin (Zartman and Smith, 1975; Fechheimer and Jaap, 1978). The occurrence of two triploid turkey embryos, with only the ZZZ sex chromosomes, might have resulted from diandry or from digyny, originating from a suppression of meiosis II during oogenesis (Fechheimer, 1981; Thorne and Sheldon, 1991; de la Sena et al., 1992). In the 4 diploid/tetraploid turkey embryos the sex chromosome complement of the diploid cells was doubled in the tetraploid cells, what indicates that, similarly as in chicken, tetraploid cells were produced by endoreduplication or suppression of cytokinesis during early cleavage mitosis (Miller et al., 1971). In C- banded diploid/tetraploid quail embryos, $\mathrm{C}$-band variants of chromosome 4 and chromosome $\mathrm{Z}$ in diploid cells were also doubled in tetraploid cells (de la Sena et al., 1991).

TABLE 1

Number and percentages (in parentheses) of heteroploid embryos

\begin{tabular}{lccc}
\hline & \multicolumn{2}{c}{ Line } & \\
\cline { 2 - 3 } Abnormality & $\begin{array}{c}\text { medium-heavy } \\
\text { weight }\end{array}$ & $\begin{array}{c}\text { heavy } \\
\text { weight }\end{array}$ & Total \\
& MHW & HW & \\
\hline Haploidy (1A) & $10(7.7)$ & $4(1.6)$ & $14(3.7)$ \\
Haploid/diploid chimerism (1A/2A) & $8(6.1)$ & $12(4.8)$ & $20(5.3)$ \\
Triploidy (3A) & - & $2(0.8)$ & $2(0.5)$ \\
Diploid/tetraploid mosaicism (2A/4A) & $2(1.5)$ & $2(0.8)$ & $4(1.0)$ \\
Total heteroploid embryos & $20(15.4)^{1}$ & $20(8.0)^{1}$ & $40(10.5)$ \\
Total number of embryos & 130 & 248 & 378 \\
\hline
\end{tabular}

${ }^{1} \mathrm{P} \leq 0.043$

TABLE 2

Sex chromosome complement of turkey embryos with chromosome abnormalities

\begin{tabular}{|c|c|c|c|c|}
\hline \multirow[b]{2}{*}{ Abnormality } & \multicolumn{2}{|c|}{ MHW line } & \multicolumn{2}{|c|}{ HW line } \\
\hline & $\begin{array}{c}\text { number } \\
\text { of } \\
\text { embryos }\end{array}$ & $\begin{array}{c}\text { sex } \\
\text { chromosome } \\
\text { complement }\end{array}$ & $\begin{array}{c}\text { number } \\
\text { of } \\
\text { embryos }\end{array}$ & $\begin{array}{c}\text { sex } \\
\text { chromosome } \\
\text { complement }\end{array}$ \\
\hline Haploidy (1A) & 10 & Z & 4 & Z \\
\hline \multirow[t]{2}{*}{ Haploid/diploid chimerism $(1 \mathrm{~A} / 2 \mathrm{~A})$} & 5 & $\mathrm{Z} / \mathrm{ZZ}$ & 8 & $\mathrm{Z} / \mathrm{ZZ}$ \\
\hline & 3 & $\mathrm{Z} / \mathrm{ZW}$ & 4 & $\mathrm{Z} / \mathrm{ZW}$ \\
\hline Triploidy (3A) & - & - & 2 & $\mathrm{ZZZ}$ \\
\hline \multirow[t]{2}{*}{ Diploid/tetraploid mosaicism (2A/4A) } & - & - & 1 & ZZ/ZZZZ \\
\hline & 2 & ZW/ZZWW & 1 & ZW/ZZWW \\
\hline
\end{tabular}


In the literature available there is no data concerning chromosome abnormalities in turkey embryos. A comparison of the frequency of chromosome aberrations observed in the present study, with that reported for other bird species, indicates that in turkeys this is a frequent phenomenon (Reddy and Siegel, 1977; Wolowodiuk et al., 1995; Jaszczak et al., 1999). A significantly greater frequency of chromosome abnormalities in the MHW than HW line can result from genetic differences between the components used for creating commercial turkey lines. Individual lines or strains of chicken are characterized by a large variation in the overall rate of chromosome aberrations in embryos (Thorne and Sheldon, 1991; Jaszczak et al., 1993). For that reason it is necessary to conduct further cytogenetic studies of chromosome abnormalities in the parent stock used for creating commercial lines. The results obtained indicate the value of a cytogenetic survey of turkeys aiming at an elimination of the carriers of chromosome aberrations, as those may be the reason of a lower hatchability of fertile eggs.

\section{ACKNOWLEDGEMENTS}

The authors thank Zofia Piechal for technical assistance.

\section{REFERENCES}

Bloom S.E., 1972. Chromosome abnormalities in chicken (Gallus domesticus) embryos: types, frequencies and phenotypic effects. Chromosoma 37, 309-326

de la Sena C.A., Fechheimer N.S., Nestor K.E., 1991. Variability of C-banding patterns in the Japanese quail. Genome 34, 993-997

de la Sena C.A., Fechheimer N.S., Nestor K.E., 1992. Evidence for genetic etiology of heteroploidy in embryos of the Japanese quail (Coturnix coturnix japonica). Cytogenet. Cell Genet. 60, 140-145

Fechheimer N.S., 1981. Origins of heteroploidy in chicken embryos. Poultry Sci. 60, 1365-1371

Fechheimer N.S., Jaap R.G., 1978. The parental source of heteroploidy in chick embryos determined with chromosomally marked gametes. J. Reprod. Fertil. 52, 141-146

Jaszczak K., Cywa-Benko K., Wężyk S., 1992. Chromosome abnormalities in early embryos from chickens maintaining in preservable flocks. Rocz. Nauk. Zoot., Monogr. Rozpr. 31, 285-294

Jaszczak K., Jaszczak J., 1993. Chromosomal abnormalities in early embryos and commercial chicks and hatchability in reproduction flocks of layer and broiler hens. Genet. Pol. 34, 287-293

Jaszczak K., Rabsztyn A., Jaszczak J., Kapkowska E., 1999. A karyotypic survey of early goose embryoos. Anim. Sci. Pap. Rep. 17, 67-72

Miller R.C., Fechheimer N.S., Jaap R.G., 1971. Chromosome abnormalities in 16- to 18-hour chick embryos. Cytogenetics 10, 121-136

Miller R.C., Fechheimer N.S., Jaap R.G., 1976. Distribution of karyotype abnormalities in chick embryo sibships. Biol. Reprod. 14, 549-560 
Reddy P.R.K., Siegel P.B., 1977. Chromosomal abnormalities in chickens selected for high and low body weight. J. Hered. 68, 253-256

Snyder M.D., Fechheimer N.S., Jaap R.G., 1979. Incidence and origin of heteroploidy, especially haploidy, in chick embryos from intraline and interline matings. Cytogenet. Cell Genet. 14, 63-75

Thorne M.H., Collins R.K., Sheldon B.L., 1991. Chromosome analysis of early embryonic mortality in layer and broiler chicken. Brit. Poultry Sci. 32, 711-722

Thorne M.H., Sheldon B.J., 1991. Cytologigal evidence of maternal meiotic errors in a line of chickens with a high incidence of triploidy. Cytogenet. Cell Genet. 57, 206-210

Wolowodiuk D., Fechheimer N.S., Nestor K.E., Bacon W.L., 1985. Chromosome abnormalities in embryos from lines of Japanese quail divergently selected for body weight. Genet. Sel. Evol. $17,183-190$

Zartman D.L., Jaszczak K., 1980. A procedure for chromosome preparations from early chick embryos. Pr. Mat. Zoot. 23, 115-119

Zartman D.L., Smith A.L., 1975. Triploidy and haploid-triploid mosaicsm among chick embryos (Gallus domesticus). Cytogenet. Cell Genet. 15, 138-145

\section{STRESZCZENIE}

\section{Nieprawidłowości chromosomowe we wezesnych zarodkach indyków}

Badano kariotypy wczesnych zarodków (24 godz.) z dwóch komercyjnych linii indyków: średnio ciężkiej (Nicholas 300) i ciężkiej (Nicholas 700). Spośród przeanalizowanych łącznie 378 zarodków nieprawidłowości chromosomowe stwierdzono w 40 przypadkach (10,5\%); najczęściej występował chimeryzm haploidalno/diploidalny (20) i haploidia (14). W badanym materiale były poza tym dwa zarodki triploidalne i dwa z mozaicyzmem diploidalno/tetraploidalnym. Istotnie większa częstotliwość heteroploidalnych zarodków wystąpiła w linii średnio ciężkiej $(15,4 \%)$ niż w linii ciężkiej $(8,0 \%)$. $\mathrm{W}$ dyskusji wskazano na negatywny efekt nieprawidłowości chromosomowych w reprodukcji. 